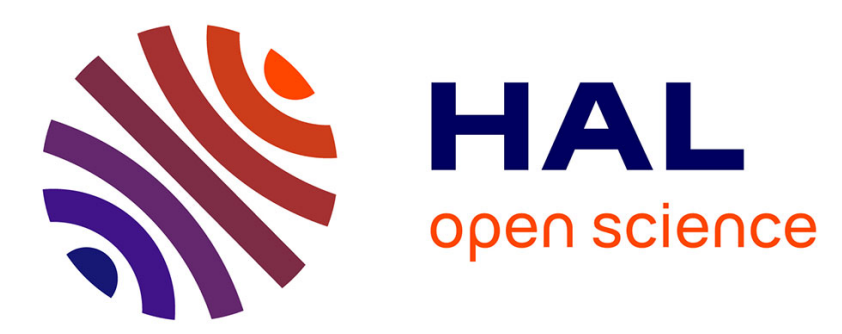

\title{
Validation of reference genes for gene expression studies in the honey bee, Apis mellifera, by quantitative real-time RT-PCR
}

Anete Pedro Lourenço, Aline Mackert, Alexandre dos Santos Cristino, Zilá Luz Paulino Simões

\section{To cite this version:}

Anete Pedro Lourenço, Aline Mackert, Alexandre dos Santos Cristino, Zilá Luz Paulino Simões. Validation of reference genes for gene expression studies in the honey bee, Apis mellifera, by quantitative real-time RT-PCR. Apidologie, 2008, 39 (3), pp.372-385. hal-00891936

\section{HAL Id: hal-00891936 https://hal.science/hal-00891936}

Submitted on 1 Jan 2008

HAL is a multi-disciplinary open access archive for the deposit and dissemination of scientific research documents, whether they are published or not. The documents may come from teaching and research institutions in France or abroad, or from public or private research centers.
L'archive ouverte pluridisciplinaire HAL, est destinée au dépôt et à la diffusion de documents scientifiques de niveau recherche, publiés ou non, émanant des établissements d'enseignement et de recherche français ou étrangers, des laboratoires publics ou privés. 


\title{
Validation of reference genes for gene expression studies in the honey bee, Apis mellifera, by quantitative real-time RT-PCR*
}

\author{
Anete Pedro Lourenço ${ }^{1}$, Aline MACKerT ${ }^{1}$, Alexandre dos Santos CRISTINo ${ }^{2}$, \\ Zilá Luz Paulino SIMÕES ${ }^{3}$
}

\author{
${ }^{1}$ Departamento de Genética, Faculdade de Medicina de Ribeirão Preto, Universidade de São Paulo, Avenida \\ Bandeirantes, 3900, 14040-900, Ribeirão Preto, SP, Brazil \\ ${ }^{2}$ Instituto de Matemática e Estatística, Universidade de São Paulo, Rua do Matão, 1010, 05508-090, Cidade \\ Universitária, São Paulo, SP, Brazil \\ ${ }^{3}$ Departamento de Biologia, Faculdade de Filosofia, Ciências e Letras de Ribeirão Preto, Universidade de São \\ Paulo, Avenida Bandeirantes, 3900, 14040-901, Ribeirão Preto, SP, Brazil
}

Received 8 October 2007 - Revised 28 January 2008 - Accepted 14 February 2008

\begin{abstract}
For obtaining accurate and reliable gene expression results it is essential that quantitative realtime RT-PCR (qRT-PCR) data are normalized with appropriate reference genes. The current exponential increase in postgenomic studies on the honey bee, Apis mellifera, makes the standardization of qRT-PCR results an important task for ongoing community efforts. For this aim we selected four candidate reference genes (actin, ribosomal protein 49, elongation factor 1-alpha, tbp-association factor) and used three software-based approaches (geNorm, BestKeeper and NormFinder) to evaluate the suitability of these genes as endogenous controls. Their expression was examined during honey bee development, in different tissues, and after juvenile hormone exposure. Furthermore, the importance of choosing an appropriate reference gene was investigated for two developmentally regulated target genes. The results led us to consider all four candidate genes as suitable genes for normalization in A. mellifera. However, each condition evaluated in this study revealed a specific set of genes as the most appropriated ones.
\end{abstract}

quantitative real-time RT-PCR / reference genes / Apis mellifera / gene expression normalization

\section{INTRODUCTION}

The advent of real-time quantitative RTPCR technology (qRT-PCR) has dramatically changed the field of gene expression analysis. It is the most sensitive and reproducible quantitative method for gene expression analysis and is now commonly used to evaluate RT-PCR data (Bustin et al., 2005; Huggett et al., 2005). For data analysis, target gene ex-

Corresponding author: A.P. Lourenço, anete@ rge.fmrp.usp.br

* Manuscript editor: Marla Spivak

Online material is available at:

http://www.apidologie.org pression is normalized with reference genes also known as housekeeping genes (Bustin, 2002). Reference genes should show similar mRNA levels at different stages of development of an organism or in different tissues, and they should not vary in abundance in response to environmental factors or bioassay treatments. Many genes involved in basic and ubiquitous cellular functions, such as $\beta$-actin, glyceraldehyde-3-phosphate dehydrogenase (GAPDH) and ribosomal $18 S(18 S)$ are frequently being used as reference genes in different organisms as they are supposed to have a uniform expression. However, several reports have indicated that differences in 
expression levels of such reference genes may exist under different experimental conditions (Shimokawa et al., 1998; Thellin et al., 1999; Suzuki et al., 2000; Lee, 2002), making their use in global gene expression studies problematic. Software-based approaches, such as geNorm (Vandesompele et al., 2002), Bestkeeper (Pfaffl et al., 2004) and NormFinder (Andersen et al., 2004), have been developed as a rational approach to determine the bestsuited genes for normalization from a panel of candidate genes in a given set of biological samples.

The honey bee Apis mellifera is a highly social insect and represents a key model for social behavior studies. Since it is also the first hymenopteran insect to have its genome fully sequenced (The Honey Bee Genome Sequencing Consortium, 2006), gene expression analyses are now a major aspect of community efforts, allowing insights into molecular mechanisms in this social insect based on candidate gene analyses. Information on putative functions of these genes can be obtained from their expression profile in development, different tissues, or experimental conditions. In addition to candidate gene approaches, the available honey bee genomic database has also supported the development and exploration of non-hypothesis driven high-throughput gene expression data, resulting from suppression subtractive hybridization protocols and microarrays (Evans and Wheeler, 2000; Whitfield et al., 2003; Judice et al., 2006). Most of the currently published gene expression studies on honey bees, e.g. Kucharski and Malezka (2005), Lourenço et al. (2005), Evans (2006), Wheeler et al. (2006), Yamazaki et al. (2006), employed reference genes by inference on their suitability obtained in other organisms, but with an expected increase in the number of qRTPCR-based transcriptome studies, a rational optimization approach to the selection and standardization of reference genes is now an important requirement.

In this study, we report quantitative analyses of the expression of four commonly used reference genes, TATA box binding protein association factor (tbp-af), actin (act), translation elongation factor 1 (efl-alpha) and ribo- somal protein 49 (rp49) to identify the most suitable reference gene(s) for expression analysis in honey bee. Stability of their expression was investigated throughout postembryonic development, in several tissues of newly emerged queens, and in worker larvae following juvenile hormone treatment. We also analyzed the normalization effect of the use each of the four reference genes on calculated expression levels of two developmentally regulated target genes, a juvenile hormone esterase-like (jhe-like) and prophenoloxidase (proPO).

\section{MATERIALS AND METHODS}

\subsection{Biological samples}

Queens and workers of Africanized honey bees, Apis mellifera L., were collected from hives of the Experimental Apiary of the Department of Genetics, University of São Paulo, Ribeirão Preto, Brazil. Standard apicultural techniques were used to rear queens by grafting first instar female larvae to queen cells. For representation of postembryonic gene expression profiles we choose three larval and two pupal stages: second instar larvae (L2), fourth instar larvae (L4), fifth instar larvae at the feeding phase (F3), early prepupae (PP1), pink-eyed pupae (Pp) and brown-eyed pupae with medium pigmented cuticle $(\mathrm{Pbm})$. Two or four undissected individuals of each stage were pooled into each sample and were homogenized in TRIzol ${ }^{\circledR}$ reagent (Invitrogen) and frozen at $-80^{\circ} \mathrm{C}$ until RNA extraction.

Pools of brain, ovary, fat body and hemocytes samples were obtained from 10 newly emerged queens. Tissues were dissected in $0.9 \%$ saline solution, extensively washed in the same solution and incubated in TRIzol ${ }^{\circledR}$ Reagent. For hemocyte extraction we punctured the abdominal intersegmental membrane and collected hemolymph using a $10 \mu \mathrm{L}$ microcapillary tube. After hemolymph centrifugation $(800 \mathrm{~g}$ for $5 \mathrm{~min}$ ) the supernatant was removed and TRIzol ${ }^{\circledR}$ was added to the hemocyte pellet.

In order to test the effect of hormonal manipulation on the expression profiles of the four candidate reference genes we removed early spinning-stage worker larvae (L5S) from their brood cells and separated them into two groups, one receiving a topical application of $10 \mu \mathrm{g}$ juvenile hormone III (JH-III, Fluka) diluted in $1 \mu \mathrm{L}$ acetone, and the other $1 \mu \mathrm{L}$ of acetone. Larvae were maintained in an incubator 
at $34{ }^{\circ} \mathrm{C}$ and $80 \%$ relative humidity for 24 hours. After that, they were homogenized individually in TRIzol $^{\circledR}$ reagent. To evaluate whether the hormone treatment was effective, jhe-like mRNA levels were tested in the samples used in this work. Transcript levels of jhe-like have previously been shown to be upregulated in JH III treated samples (Mackert et al., 2008).

\subsection{Total RNA extraction and cDNA synthesis}

Total RNA was extracted using a TRIzol ${ }^{\circledR}$ protocol (Invitrogen). The RNA extracts were incubated in the presence of DNAse I (Promega) for $30 \mathrm{~min}$ at $37^{\circ} \mathrm{C}$ to eliminate contaminating DNA. The RNA concentration of each RNA sample was measured in triplicate using a GeneQuant spectrophotometer (Pharmacia). Purity of the total RNA extracted was determined as the $260 \mathrm{~nm} / 280 \mathrm{~nm}$ ratio with expected values between 1.8 and 2. RNA integrity was determined by denaturing agarose gel (1.2\%) electrophoresis and ethidium bromide staining. For cDNA synthesis the amount of total RNA was standardized to $1 \mu \mathrm{g}$. First-strand cDNA was synthesized in triplicate by reverse transcription catalyzed by SuperScript II reverse transcriptase (Invitrogen) and an oligo $(\mathrm{dT})_{12-18}$ primer.

\subsection{Primer design}

Primers for quantitative real-time RT-PCR (qRTPCR) analysis were designed using the Primer3 program (Rozen and Skaletsky, 2000). The rp49 primers were designed to span an intron to enable detection of genomic DNA contamination. In case of genomic contamination, the rp 49 primers would have amplified a $240 \mathrm{bp}$ fragment in addition to the expected $150 \mathrm{bp}$ cDNA fragment. Using a generic dye such as SYBR green, different PCR amplicons and/or nonspecific amplification products could accurately be distinguished by analysis of the respective DNA melting/dissociation curves. This method can be used to differentiate amplification products that differ by less than $2{ }^{\circ} \mathrm{C}$ in their melting temperatures (Ririe et al., 1997). Two target genes were also included in the analysis: one coding for a juvenile hormone esterase-like carboxylesterase (jhe-like; GenBank accession number AY647436) and the other coding for prophenoloxidase ( $p r o P O$;
GenBank accession number AY242387) (Lourenço et al., 2005). These two genes were used to compare the effects of normalization by the four candidate reference genes on calculated expression levels of target genes. Primer sequences and gene characteristics are summarized in Table I.

\subsection{Cloning and sequencing}

Fourth instar larval cDNA was used as template in the PCR amplifications performed under the following conditions: $2 \mathrm{~min}$ at $94{ }^{\circ} \mathrm{C}$ followed by 25 cycles of $30 \mathrm{~s}$ at $94{ }^{\circ} \mathrm{C}, 30 \mathrm{~s}$ at $60^{\circ} \mathrm{C}(\mathrm{ex}-$ cept for tbp-af, $63{ }^{\circ} \mathrm{C}$ ), $30 \mathrm{~s}$ at $72{ }^{\circ} \mathrm{C}$ and a final extension step for $7 \mathrm{~min}$ at $72{ }^{\circ} \mathrm{C}$. To ensure amplification specificity, the respective PCR-products were analyzed in $1 \%$ agarose gels, purified, and subcloned into pGEM-T Easy Vector (Promega). These plasmids were used to chemically transform competent Escherichia coli DH5 $\alpha$. After cloning, plasmids containing the inserts were submitted to sequencing reactions using Big-dye terminator v3.0 Cycle Sequencing Ready Reaction with M13 forward and M13 reverse universal primers, followed by product analysis on an ABI Prism 310 Genetic Analyzer (Applied Biosystems).

\subsection{Real-time PCR assays}

Expression analyses were performed in two steps with reverse transcription (as described above) followed by specific real-time PCR using SYBR ${ }^{\circledR}$ GREEN methodology. Each sample was analyzed in duplicate in a total reaction of $25 \mu \mathrm{L}$, containing $10 \rho$ mol of each primer, $1 X$ SYBR Green (Applied Biosystems) and $1 \mu \mathrm{L}$ of diluted cDNA (cDNA was diluted 1:10 in water) synthesized from a standardized amount of total RNA. Reactions were performed on an ABI Prism 7500 thermocycler (Applied Biosystems) using the following cycling conditions: $50^{\circ} \mathrm{C}$ for $2 \mathrm{~min}, 95^{\circ} \mathrm{C}$ for $10 \mathrm{~min}$ and 40 cycles at $95^{\circ} \mathrm{C}$ for $15 \mathrm{~s}$ and $60^{\circ} \mathrm{C}$ or $63^{\circ} \mathrm{C}$ (tbp-af) for $1 \mathrm{~min}$. For each experiment, a nontemplate reaction was included as negative control. The specificity of the PCR products was verified by melting curve analysis for all samples and was subsequently checked electrophoretically for each primer pair.

Threshold cycle $(\mathrm{Ct})$ values were determined at the same fluorescence threshold line for each gene and the $\mathrm{Ct}$ value for each sample was obtained by calculating the arithmetic mean of two 


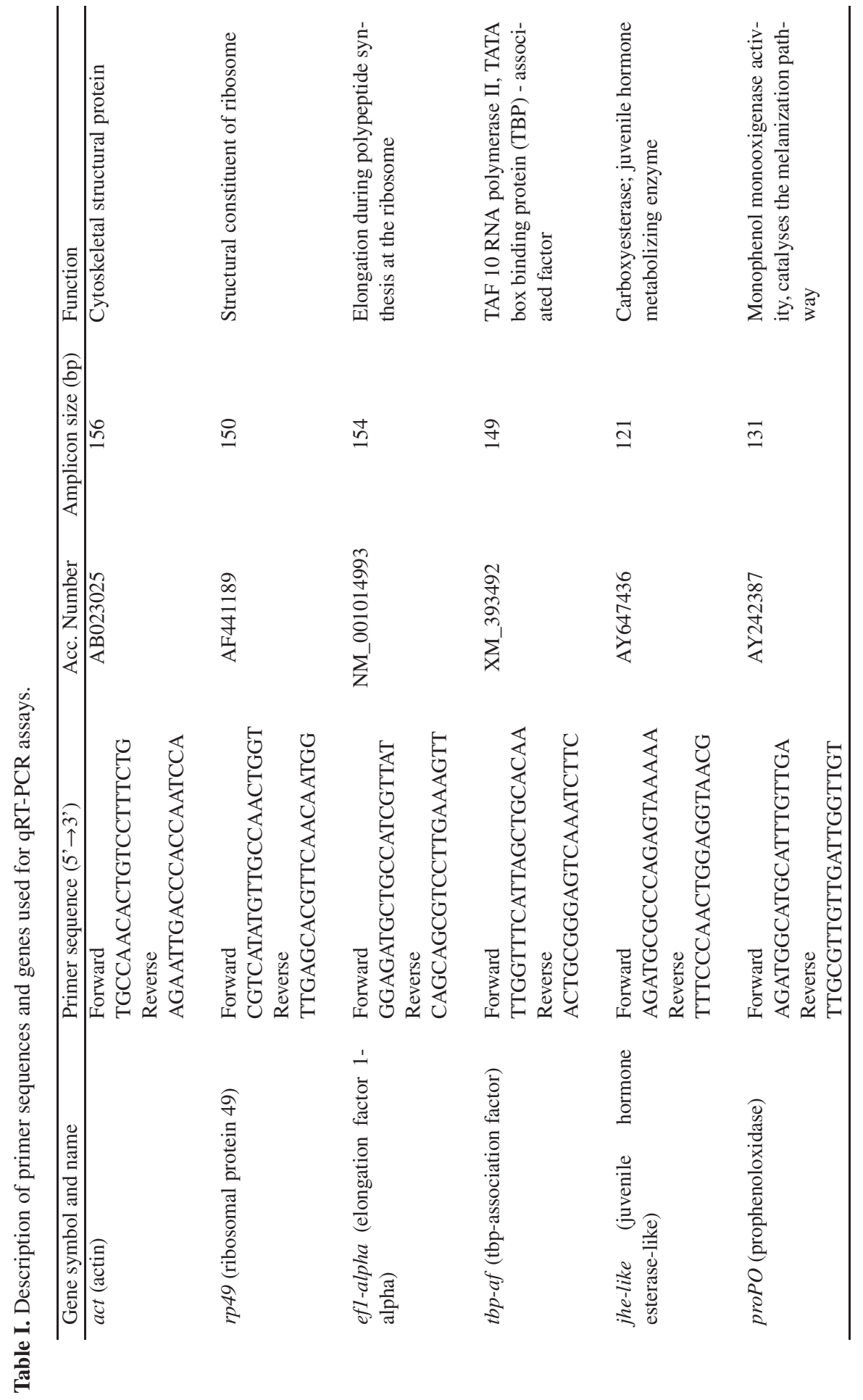


values. In some analyses, Ct values were transformed into quantity values using the comparative Ct method provided by Applied Biosystems (user bulletin \#2). Standard curves were prepared using four points with progressive quantities of plasmid DNA $\left(5 \times 10^{-1}\right.$ to $\left.5 \times 10^{-4} \eta \mathrm{g}\right)$ containing one of the six genes (tbp-af, actin, efl-alpha, rp49, jhe-like or proPO) as insert. They were previously cloned into pGEM-T Easy Vector as described above. PCR efficiency (E) values were calculated for each gene from the given slope after running standard curves and the following formula $\mathrm{E}=10^{-1 / \text { slope }}$.

\subsection{Data analysis}

Statistical analyses were performed with SigmaStat (version 3.1) and corresponding graphs were generated with Origin (version 6.0). To calculate the stability of candidate reference genes the softwares BestKeeper(C) (version 1; Pfaffl et al., 2004), geNorm $^{\mathrm{TM}}$ (version 3.4; Vandesompele et al., 2002), and NormFinder@ (version 0.953; Andersen et al., 2004) were used. These freely available software packages are Visual Basic Application tools for Microsoft Excel ${ }^{\circledR}$.

BestKeeper uses raw data (Ct values) and PCR efficiency (E) to determine the best-suited standards and combines them into an index. The software computes descriptive statistics of all derived $\mathrm{Ct}$ values for each reference gene: the geometric mean, arithmetic mean, minimal and maximal value, standard deviation, and coefficient of variance. The descriptive statistics includes the $\mathrm{x}$-fold over or under-expression of individual samples compared to the geometric mean $\mathrm{Ct}$, and the multiple factor of their minimal and maximal values expressed as the $\mathrm{x}$-fold ratio and its respective standard deviation. These $\mathrm{x}$-fold expression results are corrected via the PCR efficiency. $x$-fold values are used to analyze sample integrity trough an intrinsic variation (InVar) calculation of expression for a single sample. Samples showing 3-fold over or underexpression are removed from the analysis. High x-fold values are due to inefficient sample preparation, incomplete reverse transcription or sample degradation. The stability of reference gene expression is based on the calculated variations as standard deviation (SD) and coefficient of variance (CV). An SD higher than 1 can be considered as inconsistent and it is recommended to exclude the gene from the calculation of the Bestkeeper index. Reference genes can be ordered from the most stable, exhibiting the lowest variation, to the least stable, exhibiting the highest variation.

The geNorm program calculates a gene stability measure ( $M$ value) for a putative reference gene based on the geometric mean of all studied genes. It relies on the principle that the expression ratio of two ideal internal control genes is identical in all samples, regardless of experimental conditions or cell type. It assumes that two genes that show the best correlation in their expression levels are the most appropriate ones and that a normalization factor can be calculated from these genes. Genes with the lowest $M$ values are considered the most stable in expression. In our study, raw $\mathrm{Ct}$ values were transformed to quantities using the comparative $\mathrm{Ct}$ method, where the highest relative quantities (lowest $\mathrm{Ct}$ ) for each gene were set to 1 . These linear scale data were used as input data, according to geNorm requirements.

NormFinder calculates a stability value from a set of candidate reference genes. As input, it uses the same transformed data as geNorm. NormFinder calculates a stability value from a panel of candidate genes and it organizes them into different subgroups. This approach combines the intragroup and intergroup expression variation to a stability index that enables the ranking of genes by expression stability. A low numerical value for the stability index corresponds to a high stability in gene expression.

\section{RESULTS}

\subsection{Primer optimization and amplification specificity}

Primers were designed to amplify four commonly used reference genes (act, rp49, efl-alpha, tbp-af) and two target genes (jhelike and proPO) (see Tab. I for primers names, symbols and function). Experimental conditions that generated a sharp peak in dissociation analysis and did not present unspecific amplification fragments or primer-dimers were selected. The analysis of melting temperatures, amplicon sizes and sequencing data demonstrated the specificity of the PCR reactions. The efficiency values obtained from the real-time PCR amplification of the four reference genes ranged from 1.89 to 2.14 , and for the two target genes, jhe-like and proPO, the values were 2.21 and 2.36 , respectively. 


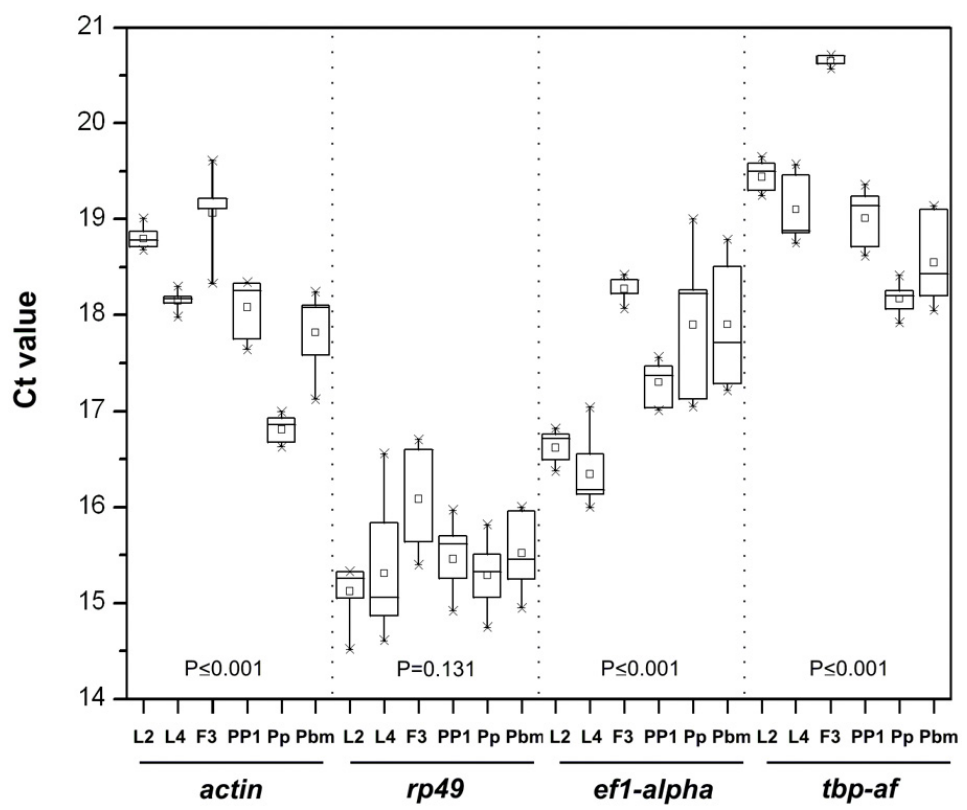

Figure 1. Box plot comparison of threshold cycles $(\mathrm{Ct})$ for the four reference genes for samples of different stages in postembryonic development of honey bee workers. $P$ value is given for each one of the four reference genes (One-Way ANOVA; Post-hoc: Holm-Sidak). Stages: second instar larvae (L2), fourth instar larvae (L4), fifth instar larvae in the feeding phase (F3), prepupa (PP1), pink-eyed pupae (Pp) and browneyed pupae with medium pigmented cuticle $(\mathrm{Pbm})$. $\square$ : represents mean value; * 1st percentile, and 99th percentile.

\subsection{Sample quality}

RNA integrity was confirmed by agarose gel electrophoresis, showing intense ribosomal RNA bands with a total absence of smears (see Online material Fig. 1). Sample integrity was also comfirmed using all reference genes through an intrinsic variance (InVar) of expression for each single sample (BestKeeper; Pfaffl et al., 2004). The InVAr of the investigated samples had low $\mathrm{Ct}$ variation as well as an appropriate $\mathrm{x}$-fold level, indicating a very good sample integrity. A removal is recommended in case of an over 3-fold over or underexpression (Pfaffl et al., 2004). In our assays, none of the samples had an $\mathrm{x}$-fold more than 1.01 (see Online material Tab. I). To ensure absence of genomic contamination we analyzed the $r p 49$ dissociation curve of each sample, making sure that alls showed only a single peak at $76{ }^{\circ} \mathrm{C}$ (see Online material Fig. 2) corresponding to the expected fragment.

\subsection{Transcription profiles of reference genes during worker development}

RNA transcript levels of the four candidate reference genes were assessed at five representative stages of honey bee development: an early larval instar (L2), a critical period for caste differentiation (L4 to F3), an early metamorphosis stage (PP1), and two pupal stages, the first being an early one ( $\mathrm{Pp})$ and the second a late one $(\mathrm{Pbm})$. The distribution of $\mathrm{Ct}$ values for each reference gene examined in samples of these developmental stages showed significant variation for act, efl-alpha and tbp-af, but not for $r p 49$ (One-Way ANOVA, $P>0.1$; Fig. 1).

Subsequent analyses were performed using the three software programs. At a first analysis of the data based on the inspection of raw $\mathrm{Ct}$ values, BestKeeper revealed an overall stability in gene expression with $\mathrm{Ct}$ values varying from 14.79 to 20.67 (Tab. II). Since all 
Table II. Descriptive statistics of four reference genes calculated via BestKeeper.

\begin{tabular}{|c|c|c|c|c|c|c|c|c|c|c|c|c|}
\hline & \multicolumn{4}{|c|}{ Development } & \multicolumn{4}{|c|}{ Tissues } & \multicolumn{4}{|c|}{ JH III treatment } \\
\hline & actin & rp49 & efl-alpha & $t b p-a f$ & actin & rp49 & efl-alpha & $t b p-a f$ & actin & $r p 49$ & efl-alpha & $t b p-a f$ \\
\hline $\mathrm{N}$ & 17 & 17 & 17 & 17 & 12 & 12 & 12 & 12 & 6 & 6 & 6 & 6 \\
\hline Ct geo Mean & 18.05 & 15.42 & 17.31 & 19.04 & 20.46 & 17.94 & 18.02 & 21.09 & 21.37 & 18.09 & 18.26 & 21.83 \\
\hline Ct ar Mean & 18.07 & 15.43 & 17.33 & 19.06 & 20.48 & 17.95 & 18.04 & 21.10 & 21.37 & 18.10 & 18.26 & 21.83 \\
\hline $\mathrm{Ct} \min$ & 16.66 & 14.79 & 16.07 & 17.99 & 19.70 & 17.48 & 17.35 & 20.43 & 20.90 & 17.57 & 18.11 & 21.49 \\
\hline Ct max & 19.17 & 16.18 & 18.65 & 20.67 & 22.12 & 18.63 & 19.49 & 22.27 & 21.87 & 19.01 & 18.74 & 22.04 \\
\hline$\pm \mathrm{Ct} \mathrm{SD}$ & 0.59 & 0.24 & 0.67 & 0.60 & 0.76 & 0.29 & 0.67 & 0.63 & 0.32 & 0.46 & 0.16 & 0.11 \\
\hline$\% \mathrm{CtCV}$ & 1.54 & 1.19 & 1.64 & 1.56 & 3.72 & 1.60 & 3.72 & 2.97 & 1.48 & 2.54 & 0.87 & 0.52 \\
\hline$x$-fold min & -2.78 & -1.63 & -2.48 & -1.95 & -1.75 & -1.43 & -1.63 & -1.53 & -1.42 & -1.48 & -1.11 & -1.24 \\
\hline $\mathrm{x}$-fold max & 2.26 & 1.77 & 2.64 & 2.81 & 3.37 & 1.69 & 2.92 & 2.11 & 1.44 & 2.01 & 1.42 & 1.14 \\
\hline$\pm \mathrm{x}$-fold SD & 1.54 & 1.19 & 1.64 & 1.56 & 1.75 & 1.23 & 1.63 & 1.58 & 1.26 & 1.40 & 1.12 & 1.09 \\
\hline
\end{tabular}

Abbreviations: n: number of samples; $\mathrm{Ct}$ geo Mean: geometric mean of $\mathrm{Ct}$; $\mathrm{Ct}$ ar Mean: arithmetic mean of $\mathrm{Ct}$; $\mathrm{Ct}$ min and $\mathrm{Ct}$ max: extreme values of $\mathrm{Ct}$; $\pm \mathrm{Ct} \mathrm{SD}$ : standard deviation of the $\mathrm{Ct}$; \% Ct CV: coefficient of variance expressed as a percentage on the $\mathrm{Ct}$ level; $\mathrm{x}$-fold min and $\mathrm{x}$-fold max: the extreme values of expression levels expressed as an absolute $\mathrm{x}$-fold over or under-regulation coefficient; $\pm \mathrm{x}$-fold SD: standard deviation of the absolute regulation coefficients.

tested reference genes exhibit a standard deviation (SD) value less than 1 , none of these can be considered as inconsistent, and, therefore, none had to be excluded (Pfaffl et al., 2001). Based on SD of the Ct values, rp49 and actin were the most stable expressed genes throughout honey bee development (Tab. II). The analyses conducted with geNorm ranked the reference genes according to the determined control gene stability measure (M) from the most stable (lowest $M$ value) to the least stable one (highest $\mathrm{M}$ value): actin/tbp-af - rp49 - eflalpha (Tab. III). All these genes reached high expression stability with low $\mathrm{M}$ values. These were less than 0.8 (Tab. III) and, thus, below the limit of $\mathrm{M}=1.5$ (Vandesompele et al., 2002). Using NormFinder, the ranking of the reference genes was the same for BestKeeper, except for the positions of tbp-af and actin, which are inverted (Tab. III).

\subsection{Transcription profiles of reference genes in different tissues}

Comparing samples of tissues (fat body, ovary, brain, hemocytes) of newly-emerged queens, the candidate reference genes showed $\mathrm{Ct}$ values between 22.27 and 17.35 (Fig. 2, Tab. II). Transcript levels for all genes varied significantly among the different tissues (Fig. 2). Furthermore, whereas BestKeeper showed that $r p 49$ has the lowest expression variation from all candidate genes (Tabs. II and III), geNorm (Tab. III) and NormFinder revealed actin and efl-alpha as the two best suitable reference genes (Tab. III). However, the SD calculated by BestKeeper for all the reference genes tested in this study revelead low values, indicating that all genes are equally suited as reference genes (Tab. II). Moreover, the average $\mathrm{M}$ values returned by geNorm analysis showed high expression stability for all reference genes (Tab. III).

\subsection{Effect of JH-III treatment on transcription profiles of reference genes}

Experimental treatment on the expression of the four candidate genes was evaluated in worker larvae 24 hours after these had received $1 \mu \mathrm{g}$ JH-III. None of the four reference genes showed any significant change in expression level in consequence of this hormone application (Fig. 3; t-test, $P>0.1$ ). Even though there was no significant variation in reference gene expression between control and hormone treated samples, we analyzed all data using the three software program. BestKeeper and geNorm confirmed the very high expression stability for all of the analyzed 


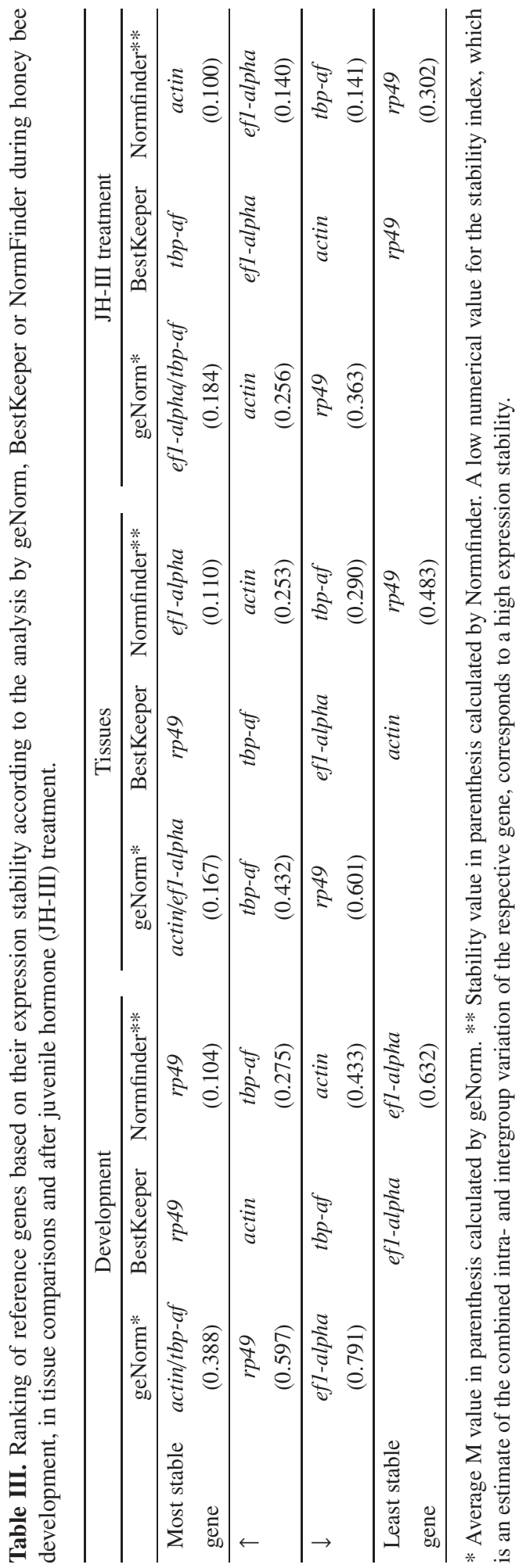




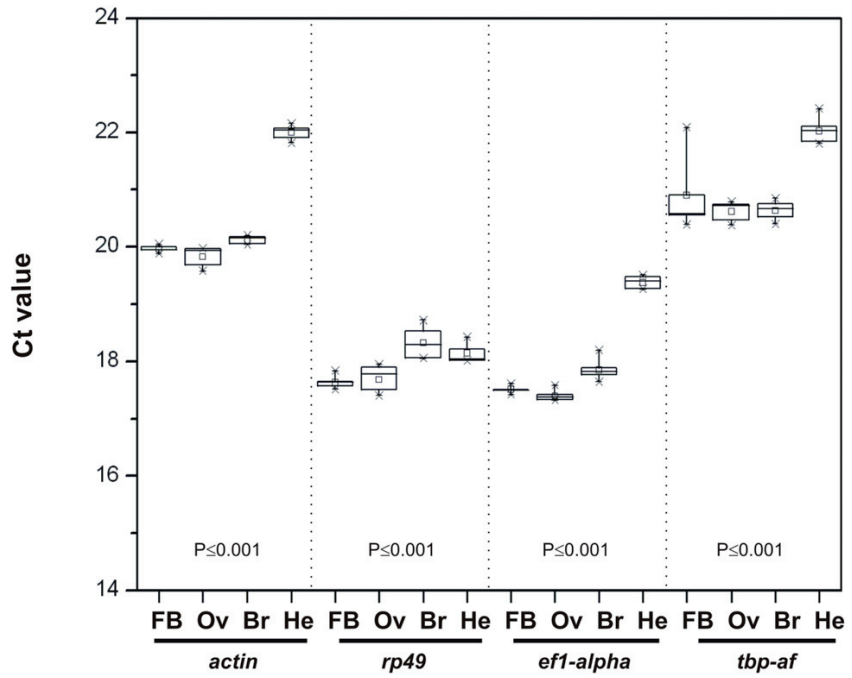

Figure 2. Box plot comparison of threshold cycles $(\mathrm{Ct})$ for the reference genes in different tissues of newly emerged queens. $P$ value is given for each one of the four reference genes (One-Way ANOVA; Post-hoc: Holm-Sidak). Tissues: fat body (FB), ovary (Ov), brain (Br) and hemocytes (He). $\square$ : represents mean value; * 1st percentile, and 99th percentile.

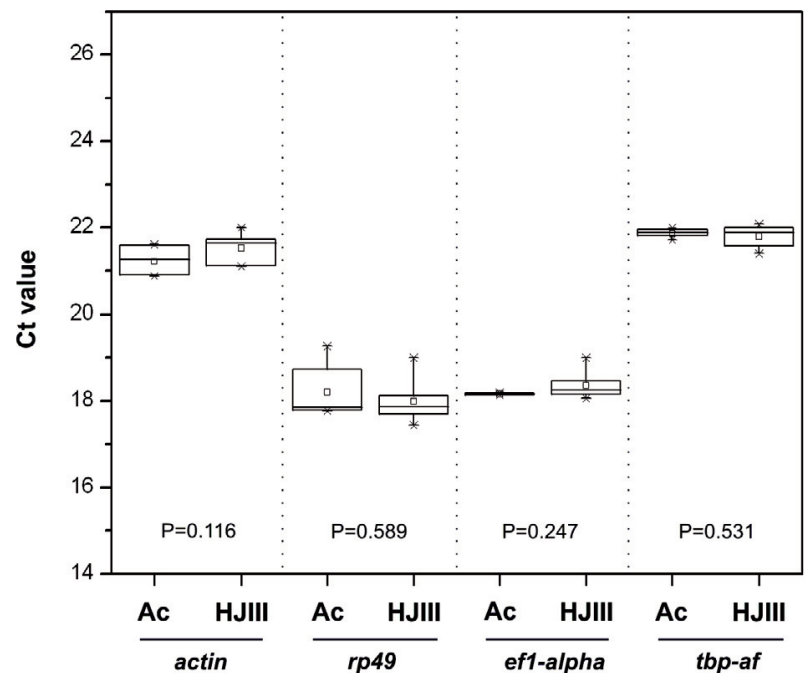

Figure 3. Box plot comparison of threshold cycles $(\mathrm{Ct})$ for the four reference genes in larvae following juvenile hormone treatment. $P$ value is given for each one of the four reference genes (t-test). $\square$ : represents mean value; $* 1$ st percentile, and 99 th percentile. 


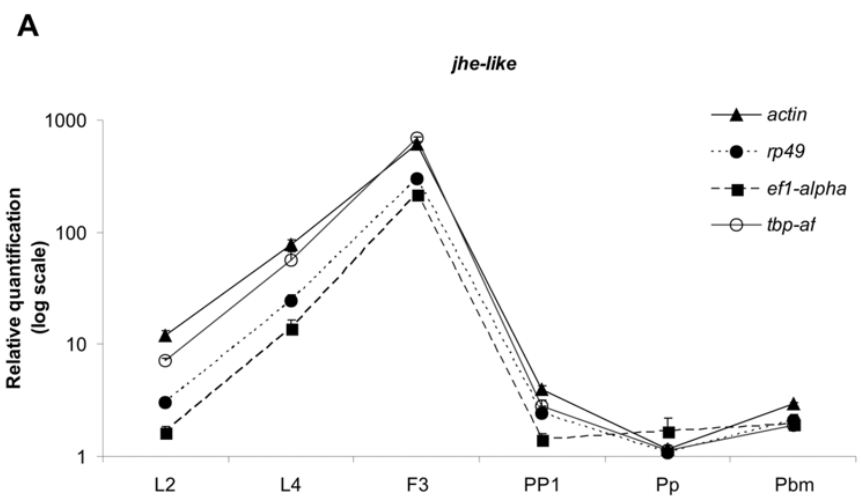

B

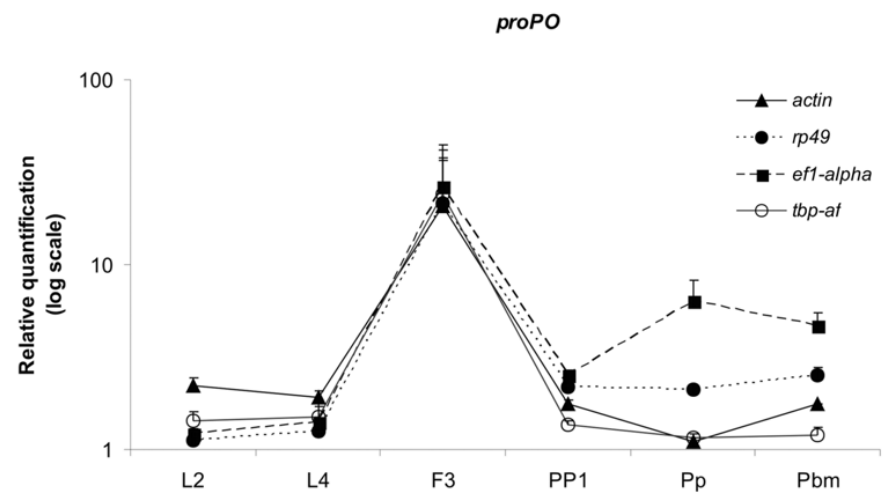

Figure 4. Relative quantification (log scale) of two developmentally regulated genes in worker larvae and pupae. Expression levels of each of the two genes were calculated separately for each of the four reference gene. (A) Expression levels of a honey bee juvenile hormone esterase (jhe-like) and (B) of a prophenoloxidase (proPO). Each point in the graph represents the mean \pm S.E of three samples. Stages: second instar larva (L2), fourth instar larva (L4), fifth instar larva in the feeding phase (F3), prepupa (PP1), pink-eyed pupa (Pp) and brown-eyed pupa with medium pigmented cuticle ( $\mathrm{Pbm})$.

reference genes (Tabs. II and III). According to BestKeeper, the lowest variation in $\mathrm{Ct}$ values was observed for tbp-af and efl-alpha (Tabs. II and III). These two genes were also considered the best suitable ones by geNorm (Tab. III). NormFinder considered actin as the most stable gene, with efl-alpha and tbp-af being the third and fourth best gene, respectively (Tab. III).

\subsection{Effect of reference gene choice on target gene analysis}

Since ideal reference genes do not exist, variation in transcript levels under specific conditions can markedly affect interpretations of target gene expression levels. We investigated the effects of reference gene choice on two genes, jhe-like (Mackert et al., 2008) and proPO (Lourenço et al., 2005) (Tab. I), both of which are modulated in their expression during honey bee development.

Real-time PCR data obtained for jhe-like and $p r o P O$ were normalized by each of the four reference genes. The relative quantification for jhe-like expression showed a slight variation in the L2, L4, F3, PP1 and Pbm stages (One-Way ANOVA, $P \leqslant 0.01$ ) mostly because of efl-alpha and rp49 normalization 
(Fig. 4A). For proPO, relative quantifications varied for L2, PP1, Pp and Pbm (One-Way ANOVA, $P \leqslant 0.01$ ) when the normalization was performed with actin, rp49 and efl-alpha (Fig. 4B). Normalization using efl-alpha presented the largest variation for both target genes. This reference gene was, therefore, considered the least stable one for all types of analyses (Tab. III). However, the variation among the samples using all four references genes for normalization was rather small and did not drastically change the target gene expression profiles.

\section{DISCUSSION}

The importance of reference genes and the need to validate them for each experimental system has already been stressed in several publications (Bustin, 2002; Vandesompele et al., 2002). For this end, several qRTPCR approaches for normalization have been developed using different statistical models (Vandesompele et al., 2002; Andersen et al., 2004; Pfaffl et al., 2004; Szabo et al., 2004; de Kok et al., 2005; Silver et al., 2006).

Herein, we attempted to identify the bestsuited reference genes to be used in qRT-PCR in analyses with samples from developmental stages, different tissues and after hormone treatment assays in the honey bee, Apis mellifera. As far as we know, this is the first systematic study comparing different candidate reference genes for qRT-PCR in honey bees. In previous qRT-PCR studies on this species, reference genes have been selected based on consensus and experience in other organisms, such as ribosomal protein S5-rpS5 (Evans, 2004; Zou et al., 2006), efl-alpha (Yamazaki et al., 2006), rp49 (Grozinger et al., 2003; Corona et al., 2007), and actin (Lourenço et al., 2005; Bitondi et al., 2006). In a systematic approach to find the best-suited reference genes for qRT-PCR in honey bees, we analyzed the behavior of four candidate reference genes (act, rp49, efl-alpha and tbp-af) by statistical analyses of variation in different biological conditions and entered these data into three established software programs for reference gene selection, geNorm, BestKeeper and
NormFinder. Even though there were slight differences in variation for the four reference genes, they showed very stable expression according to BestKeeper and geNorm. Probably as an outcome of this relative stability there was no consensus by the three software programs in ranking them in order of expression stability.

The analyses for postembryonic development revealed that the most stable genes are actin and tbp-af according to geNorm, and are ranked as the second most stable genes by BestKeeper and NormFinder, respectively. Our results are in accordance with reference gene analyses in mouse embryos, which also identified $t b p$ and $a c t b$ as the most stable ones (Willems et al., 2006), but also in this case, their stability depended on the experimental approach, since $a c t b$ was considered as an unsuitable reference gene in several other cell types or species (Schmittgen and Zakrajsek, 2000; de Kok et al., 2005). In our study, rp49 is also indicated as the best reference gene for this set of samples according to BestKeeper and Normfinder. Furthermore, the statistical analysis showed that rp49 is the only gene among all candidates for which changes in expression levels were not significant $(P=$ $0.131)$. Yet, in spite of these differences in reference gene ranking, all four reference genes consistently showed the highest mRNA levels in the F3 stage (Fig. 1). The regulation of these genes during development, thus appears to occur in a coordinate manner and is probably related to physiological differences among the larval and pupal stages. These are stages of marked change in behavior (feeding, spinning) and in physiological processes related to molting, metamorphosis and melanization.

Similar differences in reference gene ranking were observed in tissue comparisons and in larvae that were experimentally treated with JH-III. According to geNorm, actin/efl-alpha are the best genes to be used in tissue sample comparisons, whereas according to BestKeeper and NormFinder the best are $r p 49$ and efl-alpha, respectively. Comparing the different tissues, all genes varied significantly (Fig. 2). Nevertheless BestKeeper and geNorm confirmed all of the candidate reference genes as stably expressed. 
When considering the samples treated with JH-III, the most stable genes were eflalpha/tbp-af (geNorm), tbp-af (BestKeeper) and actin (NormFinder), respectively. However, there was no significant difference in mRNA levels for all reference genes between control (acetone) and JH-III treated workers (Fig. 3), indicating that all genes tested in this study can be used as reference genes to compare control and JH-III treated bees. Juvenile hormone as well as ecdysteroid titers are critical factors for caste development and metamorphosis in the last larval instar of the honey bee. Juvenile hormone, which is of prime importance for the control of caste development, shows a caste-specific peak in fourth and early fifth instar queen larvae (Rachinsky et al., 1990).

We also showed the importance of testing candidate reference genes during honey bee development. The expression of two very different target genes, jhe-like and proPO, showed that normalization with an inappropriate reference gene can have an impact on quantitative expression analyses, especially in samples with low mRNA levels.

Table III gives a combined overview on reference gene ranking in each of the programs tested in this study. Taken together, the results showed that there is no best universal reference gene for qRT-PCR studies with honey bees. For instance, rp 49 was identified as the most stable reference gene for developmental studies, but it turned out to be the least stable one for JH treatment assays. As a way out of this dilemma, Vandesompele et al. (2002) suggested that normalization should be based on more than one reference gene to achieve accuracy and statistical power. Following this general suggestion, and in spite of the fact that all four genes tested in this study were objectively suitable to be used as reference genes, we elected actin, tbp-af and rp49 as the most reliable ones for comparisons when investigating gene expression in developmental stages. For tissues samples, we suggest to use actin, efl-alpha and tbp-af for adequate normalization. Even though there was no difference in reference gene expression data when comparing $\mathrm{JH}$ treated with control bees, actin, eflalpha and tbp-af were most frequently scored as the most stably expressed, reference genes (Tab. III).

In conclusion, we tested the suitability of four reference genes with three commonly used analysis programs and confirmed that all four candidate reference genes are suitable for normalization in the honey bees samples studied. We propose to use at least two genes out of this set of four depending on the question or context to be investigated. Such choice should result in accurate and reliable normalization of qRT-PCR results for gene expression studies in honey bees under a variety of conditions.

\section{ACKNOWLEDGEMENTS}

We thank Luiz Roberto Aguiar for technical assistance in the apiary of Ribeirão Preto and Klaus Hartfelder for critical reading of this manuscript. This work was supported by FAPESP/Brazil (05/03926-5).

Validation des gènes de référence pour les études d'expression génique chez l'Abeille domestique, Apis mellifera, au moyen de la RT-PCR en temps réel.

Apis mellifera / expression génique / gène de référence / normalisation / Rt-PCR quantitative

Zusammenfassung - Validierung von Referenzgenen für Studien zur Genexpression bei der Honigbiene, Apis mellifera, mittels quantitativer real-time RT-PCR. Die quantitative real-time RTPCR (qRT-PCR) Methode enwickelt sich zu einer der am häufigsten benutzten Methode zur Quantifizierung von mRNAs. Für exakte und zuverlässig reproduzierbare Ergebnisse ist es allerdings notwendig, dass die jeweiligen qRT-PCR Werte mittels eines geeigneten Referenzgens normalisiert werden. Trotz der Verfügbarkeit von ReferenzgenStudien bei verschiedenen Organismen ist die Bewertung geeigneter Referenzgene für den jeweiligen Organismus, in diesem Fall die Honigbiene Apis mellifera, erforderlich. Genau dies war das Ziel der vorliegenden Untersuchung, und dafür wählten wir folgende Gene als Kandidaten aus: actin, rp49, efl-alpha and tbp-af (Tab. I). Diese wurden mittels der Computerprogramme geNorm, BestKeeper und Normfinder auf ihre Eignung und Eigenschaften als Referenzgene getestet. Wir untersuchten dies in verschiedenen biologischen Zusammenhängen: in verschiedenen Phasen der postembryonalen Entwicklung, in verschiedenen Geweben und Organen und nach Behandlung mit Juvenilhormon (JH-III). 
Für Studien zur Postembryonalentwicklung erwiesen sich bei Verwendung von geNorm actin und tbp-af und bei Verwendung von BestKeeper und NormFinder rp49 als die jeweils stabilsten Gene (Tab. II und III). Trotz dieser Unterschiede in der Rangfolge der Eignung zeigten alle vier Referenzgene für das Entwicklungsstadium F3 die höchsten mRNA-Werte an (Abb. 1). Dies weist darauf hin, dass die Regulierung der Genexpression in der Entwicklung in weitem Maße korreliert ist, und dass sie in der Larval- und Pupalentwicklung wahrscheinlich stark von physiologischen Faktoren beeinflusst wird. Ähnliche Unterschiede in der Eignung als Referenzgene waren auch bei den Gewebestudien und nach JH-III-Behandlung zu sehen. Während geNorm in diesen Situationen actin und efl-alpha als die am besten geeigneten Gene auswies (Tab. II und III), waren dies $r p 49$ und eflalpha, wenn BestKeeper und NormFinder als Bewertungsprogramme eingesetzt wurden (Tab. II und III). Obwohl bei den Vergleichen verschiedener Gewebe und Organe die Expressionswerte aller vier Gene signifikant schwankten (Abb. 2), wurden sie bei den BestKeeper- und geNorm-Analysen als stabile Referenz-Gene bewertet. Für Untersuchungen zu Behandlungen mit JH-III waren die stabilsten Gene efl-alpha und tbp-af (geNorm), tbp-af (BestKeeper) und actin (NormFinder) (Tab. II and III). Da wir für die Kontrollen (Aceton behandelteArbeiterinnen) und die JH-III behandelten Arbeiterinnen keine Unterschiede in der Expression dieser Gene fanden (Abb. 3), zeigt dies, dass bei solchen Versuchen alle vier Gene zur Normalisierung eingesetzt werden können.

In einem weiteren Versuchsansatz untersuchten wir, welche Auswirkungen die Auswahl von Referenzgenen auf die jeweiligen Zielgene hat. Für die Zielgene jhe-like und proPO fanden wir, dass die Normalisierung mittels eines weniger geeigneten $\mathrm{Re}$ ferenzgens eine deutliche Auswirkung auf die Berechnung der relativen Genexpressionswwerte hat, insbesondere, wenn die Proben niedrige mRNAWerte haben (Abb. 4).

Unsere Untersuchung zeigt, dass alle vier Gene im Prinzip als Referenzgene für quantitative Genexpressionsstudien bei A. mellifera eingesetzt werden können. Da jedoch jeder biologische Kontext eine jeweils andere Kombination von Referenzgenen als am besten geeignet auswies, schlagen wir vor, dass jeweils immer zwei dieser Gene für die Normalisierung verwendet werden.

Quantitative real-time RT-PCR / Referenzgene / Apis mellifera / Genexpression / Normalisierung

\section{REFERENCES}

Andersen C.L., Jensen J.L., Orntoft T.F. (2004) Normalization of real-time quantitative reverse
transcription-PCR data: a model-based variance estimation approach to identify genes suited for normalization, applied to bladder and colon cancer data sets, Cancer Res. 64 , 5245-5250.

Bitondi M.M., Nascimento A.M., Cunha A.D., Guidugli K.R., Nunes F.M., Simões Z.L. (2006) Characterization and expression of the Hex 110 gene encoding a glutamine-rich hexamerin in the honey bee, Apis mellifera, Arch. Insect Biochem. Physiol. 63, 57-72.

Bustin S.A. (2002) Quantification of mRNA using real-time reverse transcription PCR (RT-PCR): trends and problems, J. Mol. Endocrinol. 29, 2339.

Bustin S.A., Benes V., Nolan T., Pfaffl M.W. (2005) Quantitative real-time RT-PCR-a perspective, J. Mol. Endocrinol. 34, 597-601.

Corona M., Velarde R.A., Remolina S., Moran-Lauter A., Wang Y., Hughes K.A., Robinson G.E. (2007) Vitellogenin, juvenile hormone, insulin signaling, and queen honey bee longevity, Proc. Natl. Acad. Sci. USA 104, 7128-7133.

de Kok J.B., Roelofs R.W., Giesendorf B.A., Pennings J.L., Waas E.T., Feuth T., Swinkels, D.W., Span P.N. (2005) Normalization of gene expression measurements in tumor tissues: comparison of 13 endogenous control genes, Lab. Invest. 85, 154 159.

Evans J.D. (2004) Transcriptional immune responses by honey bee larvae during invasion by the bacterial pathogen, Paenibacillus larvae, J. Invertebr. Pathol. 85, 105-111.

Evans J.D. (2006) Beepath: an ordered quantitativePCR array for exploring honey bee immunity and disease, J. Invertebr. Pathol. 93, 135-139.

Evans J.D., Wheeler D.E. (2000) Expression profiles during honeybee caste determination, Genome Biol. 2, research0001.1-0001.6.

Grozinger C.M., Sharabash N.M., Whitfield C.W., Robinson G.E. (2003) Pheromone-mediated gene expression in the honey bee brain, Proc. Natl. Acad. Sci. USA 100, 14519-14525.

Huggett J., Dheda K., Bustin S., Zumla A. (2005) Realtime RT-PCR normalisation; strategies and considerations, Genes Immun. 6, 279-284.

Judice C.C., Carazzole M.F., Festa F., Sogayar M.C., Hartfelder K., Pereira G.A. (2006) Gene expression profiles underlying alternative caste phenotypes in a highly eusocial bee, Melipona quadrifasciata, Insect Mol. Biol. 15, 33-44.

Kucharski R., Maleszka R. (2005) Microarray and real-time PCR analyses of gene expression in the honeybee brain following caffeine treatment, J. Mol. Neurosci. 27, 269-276.

Lee P.D., Sladek R., Greenwood C.M., Hudson T.J. (2002) Control genes and variability: absence of ubiquitous reference transcripts in diverse mammalian expression studies, Genome Res. 12, 292 297. 
Lourenço A.P., Zufelato M.S., Bitondi M.M., Simões Z.L. (2005) Molecular characterization of a cDNA encoding prophenoloxidase and its expression in Apis mellifera, Insect Biochem. Mol. Biol. 35, 541-552.

Mackert A.S., Nascimento A.M., Bitondi M.M.G., Hartfelder K., Simões Z.L. (2008) Identification of a juvenile hormone esterase-like in the honey bee, Apis mellifera L.-expression analysis and functional assays, Comp. Biochem. Physiol. B. doi: 10.1016/j.cbpb.2008.01.004.

Pfaffl M.W., Tichopad A., Prgomet C., Neuvians T.P. (2004) Determination of stable housekeeping genes, differentially regulated target genes and sample integrity: BestKeeper-Excel-based tool using pair-wise correlations, Biotechnol. Lett. 26, 509-515.

Rachinsky A., Strambi C., Strambi A., Hartfelder K. (1990) Caste and metamorphosis: hemolymph titers of juvenile hormone and ecdysteroids in last instar honeybee larvae, Gen. Comp. Endocrinol. 79, 31-38.

Ririe K.M., Rasmussen R.P., Wittwer C.T. (1997) Product differentiation by analysis of DNA melting curves during the polymerase chain reaction, Anal. Biochem. 245, 154-160.

Rozen S., Skaletsky H. (2000) Primer3 on the WWW for general users and for biologist programmers, Methods Mol. Biol. 132, 365-386.

Schmittgen T.D., Zakrajsek B.A. (2000) Effect of experimental treatment on housekeeping gene expression: validation by real-time, quantitative RTPCR, J. Biochem. Biophys. Methods 46, 69-81.

Shimokawa T., Kato M., Ezaki O., Hashimoto S. (1998) Transcriptional regulation of musclespecific genes during myoblast differentiation, Biochem. Biophys. Res. Commun. 246, 287-292.

Silver N., Best S., Jiang J., Thein S.L. (2006) Selection of housekeeping genes for gene expression studies in human reticulocytes using real-time PCR, BMC Mol. Biol. 7, 33.

Suzuki T., Higgins P.J., Crawford D.R. (2000) Control selection for RNA quantitation, Biotechniques 29, 332-337.
Szabo A., Perou C.M., Karaca M., Perreard L., Quackenbush J.F., Bernard P.S. (2004) Statistical modeling for selecting housekeeper genes, Genome Biol. 5, research59.

The Honey Bee Genome Sequencing Consortium (2006) Insights into social insects from the genome of the honey bee Apis mellifera, Nature 443, 931-949.

Thellin O., Zorzi W., Lakaye B., De Borman B., Coumans B., Hennen G., Grisar T., Igout A., Heinen E. (1999) Housekeeping genes as internal standards: use and limits, J. Biotechnol. 75, 291295.

Vandesompele J., De Preter K., Pattyn F., Poppe B., Van Roy N., De Paepe A., Speleman F. (2002) Accurate normalization of real-time quantitative RT-PCR data by geometric averaging of multiple internal control genes, Genome Biol. 3, research0034.

Wheeler D.E., Buck N., Evans J.D. (2006) Expression of insulin pathway genes during the period of caste determination in the honey bee, Apis mellifera, Insect Mol. Biol. 15, 597-602.

Whitfield C.W., Cziko A.M., Robinson G.E. (2003) Gene expression profiles in the brain predict behavior in individual honey bees, Science 302, 296299.

Willems E., Mateizel I., Kemp C., Cauffman G., Sermon K., Leyns L. (2006) Selection of reference genes in mouse embryos and in differentiating human and mouse ES cells, Int. J. Dev. Biol. 50, 627635.

Yamazaki Y., Shirai K., Paul R.K., Fujiyuki T., Wakamoto A., Takeuchi H., Kubo T. (2006) Differential expression of HR38 in the mushroom bodies of the honeybee brain depends on the caste and division of labor, FEBS Lett. 580, 2667-2670.

Zou Z., Lopez D.L., Kanost M.R., Evans. J.D., Jiang H. (2006) Comparative analysis of serine protease-related genes in the honey bee genome: possible involvement in embryonic development and innate immunity, Insect Mol. Biol. 15, 603614. 
Apidologie 39 (2008) 372-385

\section{Online Material}




\section{SUPPLEMENTARY MATERIALS}

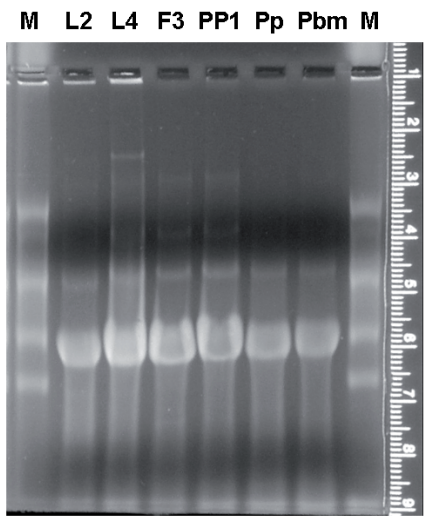

Supplementary Figure 1. Analysis of RNA integrity by denaturing formaldehyde agarose gel (1.2\%) electrophoresis. $40 \mu \mathrm{g}$ total RNA of six samples were loaded and stained with Ethidium Bromide. Note that this figure reports only some samples, however all samples were tested for this criterion. 

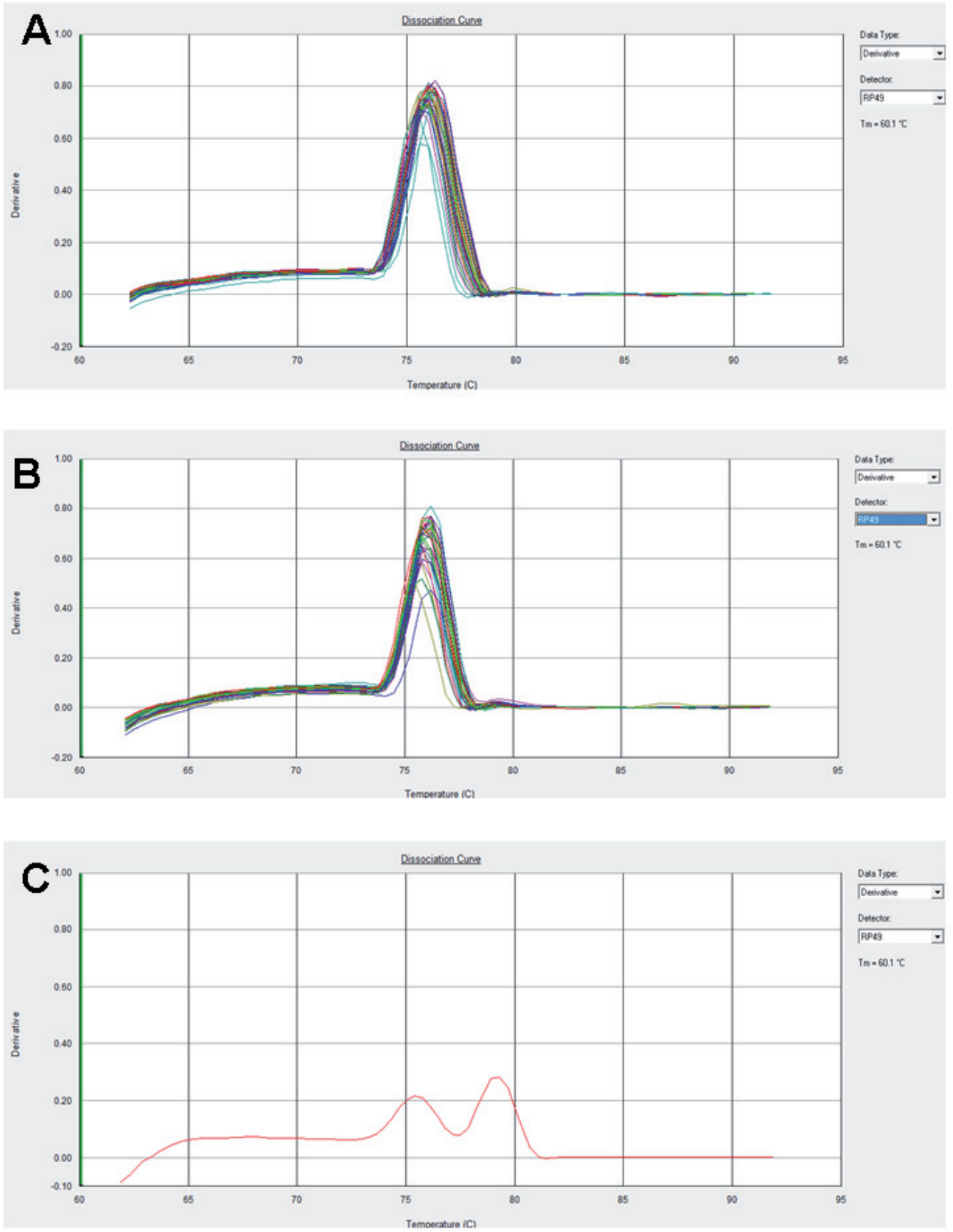

Supplementary Figure 2. Graphs showing dissociation curves after real time PCR for rp49. A and B represent curves from analyses of developmental stages (A) and tissues and hormone treatments (B). Graph $\mathrm{C}$ shows a curve for a sample (not from this study) where both cDNA and genomic fragments are amplified. Note that two peaks occur in such a case, one corresponding to the cDNA fragment $\left(76^{\circ} \mathrm{C}\right)$, also shown in graphics $\mathrm{A}$ and $\mathrm{B}$, and other one to a genomic fragment $\left(78^{\circ} \mathrm{C}\right)$. 
Supplementary Table I. Results of sample integrity: Intrinsic Variation [InVar] based on selected Housekeeping Genes; InVar index for each sample is highlighted in gray.

\begin{tabular}{|c|c|c|c|c|c|c|c|c|}
\hline & \multicolumn{8}{|c|}{ Samples from development analysis } \\
\hline & $\mathbf{n}$ & BestKeeper & $\begin{array}{l}\text { InVar. } \\
{[ \pm C P]}\end{array}$ & $\begin{array}{c}\text { InVar. } \\
{[ \pm \% \text { CP }]}\end{array}$ & $\begin{array}{c}\text { InVar. } \\
\text { [ } \pm \text { X-fold] }\end{array}$ & $\begin{array}{l}\text { InVar. } \\
{[ \pm \mathrm{CP}]}\end{array}$ & $\begin{array}{c}\text { InVar. } \\
{[ \pm \% \text { CP }]}\end{array}$ & $\begin{array}{c}\text { InVar. } \\
\text { [ } \pm \text { X-fold] }]\end{array}$ \\
\hline sample 1 & 4 & 17.46 & \pm 0.55 & \pm 3.11 & \pm 0.44 & 0.55 & 3.11 & 0.44 \\
\hline sample 2 & 4 & 17.29 & \pm 0.84 & \pm 4.82 & \pm 0.65 & 0.84 & 4.82 & 0.65 \\
\hline sample 3 & 4 & 17.48 & \pm 0.6 & \pm 3.34 & \pm 0.45 & 0.6 & 3.34 & 0.45 \\
\hline sample 4 & 4 & 16.92 & \pm 0.52 & \pm 3.06 & \pm 0.27 & 0.52 & 3.06 & 0.27 \\
\hline sample 5 & 4 & 17.04 & \pm 0.62 & \pm 3.57 & \pm 0.31 & 0.62 & 3.57 & 0.31 \\
\hline sample 6 & 4 & 17.49 & \pm 0.45 & \pm 2.59 & \pm 0.32 & 0.45 & 2.59 & 0.32 \\
\hline sample 7 & 4 & 18.48 & \pm 0.38 & \pm 1.67 & \pm 0.45 & 0.38 & 1.67 & 0.45 \\
\hline sample 8 & 4 & 18.41 & \pm 0.44 & \pm 2.01 & \pm 0.53 & 0.44 & 2.01 & 0.53 \\
\hline sample 9 & 4 & 17.57 & \pm 0.11 & \pm 0.6 & \pm 0.09 & 0.11 & 0.6 & 0.09 \\
\hline sample 10 & 4 & 17.5 & \pm 0.06 & \pm 0.32 & \pm 0.05 & 0.06 & 0.32 & 0.05 \\
\hline sample 11 & 4 & 17.18 & \pm 0.2 & \pm 1.13 & \pm 0.13 & 0.2 & 1.13 & 0.13 \\
\hline sample 12 & 4 & 16.73 & \pm 0.62 & \pm 3.32 & \pm 0.26 & 0.62 & 3.32 & 0.26 \\
\hline sample 13 & 4 & 17.2 & \pm 1.11 & \pm 6.22 & \pm 1.01 & 1.11 & 6.22 & 1.01 \\
\hline sample 14 & 4 & 17.08 & \pm 0.78 & \pm 4.37 & \pm 0.52 & 0.78 & 4.37 & 0.52 \\
\hline sample 15 & 4 & 17.13 & \pm 0.36 & \pm 1.9 & \pm 0.19 & 0.36 & 1.9 & 0.19 \\
\hline sample 16 & 4 & 17.83 & \pm 0.61 & \pm 3.5 & \pm 0.77 & 0.61 & 3.5 & 0.77 \\
\hline \multirow[t]{3}{*}{ sample 17} & 4 & 17.23 & \pm 0.53 & \pm 2.89 & \pm 0.33 & 0.53 & 2.89 & 0.33 \\
\hline & \multicolumn{8}{|c|}{ Samples from tissues analysis } \\
\hline & $\mathbf{n}$ & BestKeeper & $\begin{array}{l}\text { InVar. } \\
{[ \pm C P]}\end{array}$ & $\begin{array}{c}\text { InVar. } \\
{[ \pm \% \text { CP] }}\end{array}$ & 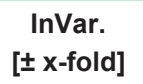 & $\begin{array}{l}\text { InVar. } \\
{[ \pm \mathrm{CP}]}\end{array}$ & $\begin{array}{c}\text { InVar. } \\
{[ \pm \% \text { CP }]}\end{array}$ & $\begin{array}{c}\text { InVar. } \\
{[ \pm x-\text { fold] }}\end{array}$ \\
\hline sample 1 & 4 & 18.82 & \pm 0.09 & \pm 0.31 & \pm 0.03 & 0.09 & 0.31 & 0.03 \\
\hline sample 2 & 4 & 18.94 & \pm 0.13 & \pm 0.7 & \pm 0.07 & 0.13 & 0.7 & 0.07 \\
\hline sample 3 & 4 & 19.21 & \pm 0.72 & \pm 3.55 & \pm 0.58 & 0.72 & 3.55 & 0.58 \\
\hline sample 4 & 4 & 18.76 & \pm 0.09 & \pm 0.25 & \pm 0.03 & 0.09 & 0.25 & 0.03 \\
\hline sample 5 & 4 & 18.82 & \pm 0.25 & \pm 1.28 & \pm 0.13 & 0.25 & 1.28 & 0.13 \\
\hline sample 6 & 4 & 18.93 & \pm 0.25 & \pm 1.4 & \pm 0.14 & 0.25 & 1.4 & 0.14 \\
\hline sample 7 & 4 & 19.26 & \pm 0.34 & \pm 1.76 & \pm 0.25 & 0.34 & 1.76 & 0.25 \\
\hline sample 8 & 4 & 19.11 & \pm 0.27 & \pm 1.32 & \pm 0.16 & 0.27 & 1.32 & 0.16 \\
\hline sample 9 & 4 & 19.23 & \pm 0.54 & \pm 2.89 & \pm 0.46 & 0.54 & 2.89 & 0.46 \\
\hline sample 10 & 4 & 20.2 & \pm 0.6 & \pm 3.13 & \pm 0.8 & 0.6 & 3.13 & 0.8 \\
\hline sample 11 & 4 & 20.48 & \pm 0.56 & \pm 2.84 & \pm 0.9 & 0.56 & 2.84 & 0.9 \\
\hline \multirow[t]{3}{*}{ sample 12} & 4 & 20.26 & \pm 0.64 & \pm 3.29 & \pm 0.91 & 0.64 & 3.29 & 0.91 \\
\hline & \multicolumn{8}{|c|}{ Samples from hormone treatment analysis } \\
\hline & n & BestKeeper & $\begin{array}{l}\text { InVar. } \\
{[ \pm \text { CP] }}\end{array}$ & $\begin{array}{l}\text { InVar. } \\
{[ \pm \% \text { CP] }}\end{array}$ & $\begin{array}{c}\text { InVar. } \\
{[ \pm x \text {-fold] }}\end{array}$ & $\begin{array}{l}\text { InVar. } \\
{[ \pm C P]}\end{array}$ & $\begin{array}{c}\text { InVar. } \\
{[ \pm \% \text { CP }]}\end{array}$ & $\begin{array}{c}\text { InVar. } \\
\text { [ } \pm \text { X-fold] }\end{array}$ \\
\hline sample 1 & 4 & 19.69 & \pm 0.16 & \pm 0.79 & \pm 0.11 & 0.16 & 0.79 & 0.11 \\
\hline sample 2 & 4 & 20.08 & \pm 0.46 & \pm 2.54 & \pm 0.5 & 0.46 & 2.54 & 0.5 \\
\hline sample 3 & 4 & 19.59 & \pm 0.21 & \pm 1.03 & \pm 0.13 & 0.21 & 1.03 & 0.13 \\
\hline sample 4 & 4 & 19.49 & \pm 0.16 & \pm 0.89 & \pm 0.09 & 0.16 & 0.89 & 0.09 \\
\hline sample 5 & 4 & 19.79 & \pm 0.2 & \pm 1.05 & \pm 0.15 & 0.2 & 1.05 & 0.15 \\
\hline sample 6 & 4 & 20.23 & \pm 0.14 & \pm 0.8 & \pm 0.14 & 0.14 & 0.8 & 0.14 \\
\hline
\end{tabular}

